\title{
SISTEM INFORMASI GEOGRAFIS UNTUK PREDIKSI PERKEMBANGAN FISIK KOTA (Studi Kasus Kota Singaraja-Bali)
}

\author{
I Wayan Krisna Eka Putra \\ Program Pascasarjana \\ Teknik Geomatika FT. UGM \\ J1. Grafika 2 Yogyakarta, 55281, Indonesia \\ E-mail address:krisna.ekaputra@yahoo.com
}

\author{
I Putu Sriartha \\ Jurusan Pendidikan Geografi, Undiksha \\ Jalan Udayana, Singaraja-Bali \\ E-mail address: psriartha@yahoo.com
}

\begin{abstract}
This study is one of the design of Geographic Information Systems (GIS) for modeling simulations to predictive of the physical development in Singaraja City, so as to provide fast data regarding the estimation of the physical development of cities among rapid land conversion activities. The method used in this study was done on a number of spatial data overlay thought to affect the physical development of the city. Each of the spatial data is weighted according to the likelihood that the effect will be given. Results from this study defines that land has been earmarked for housing and public facilities and infrastructure in Singaraja around about $39 \%$. While the predictions of the results found that the location of the most potential physical development of the city will occur at the core of the city and partly penetrated the membrane core of the city as well as suburban.
\end{abstract}

Keyword : GIS, overlay method, prediction

\section{PENDAHULUAN}

Sektor pertanian di Bali saat ini dihadapkan pada ancaman konversi lahan pertanian untuk kebutuhan-kebutuhan non-pertanian seperti industri, perumahan, jasa dan kebutuhan infrastruktur publik. Selama kurun waktu 20 tahun tercatat terjadinya penyusutan lahan seluas 10.150 ha, atau sekitar $11,5 \%$ [1]. Fenomena konversi lahan pertanian ini terjadi di semua wilayah terutama di daerah perkotaan. Jika fenomena konversi lahan pertanian ini tidak mampu dibendung, maka akan berdampak pada melemahnya ketahanan pangan, yang pada akhirnya dapat mengancam stabilitas nasional baik di bidang ekonomi, politik dan sosial budaya.

Salah satu daerah yang mengalami ancaman tinggi terjadinya proses konversi lahan di Provinsi Bali adalah Kota Singaraja. Sebagai salah satu Kota Pendidikan di Provinsi Bali dan pusat perekonomian, serta berbagai aktivitas penting lainnya, menjadikan Kota Singaraja sulit menghindar dari kegiatan konversi lahan. Menurut
Made Sumiarta [1] bahwa persawahan yang ada di Kabupaten Buleleng yaitu di pinggiran Kota Singaraja beberapa tahun terakhir terus mengalami konversi menjadi permukiman atau kawasan industri.

Proses konversi lahan yang tidak mengindahkan peraturan dan etika, akan menjadi suatu konsekuensi yang bertentangan dengan keseimbangan lingkungan, sehingga memerlukan pemutahiran penataan ruang, yang menjadi tantangan bagi pemerintah dalam upaya menjaga kelestarian lingkungan. Diberlakukannya UU No. 32 Tahun 2004 tentang Pemerintahan Daerah telah membawa perubahan mendasar dalam sistem kewenangan pemerintah pusat dan pemerintah daerah [2]. Berakhirnya pemerintahan yang sentralistik memberikan kewenangan bagi setiap daerah untuk membangun daerahnya dengan mengoptimalkan berbagai potensi lokal demi mempercepat pertumbuhan ekonomi dan pemerataan pembangunan [3]. Upaya yang sudah dilakukan oleh pemerintah daerah adalah membuat Rencana Tata Ruang Wilayah (RTRW) yang diatur dalam UU No 26 Tahun 2007 dengan tujuan untuk mewujudkan ruang wilayah nasional yang aman, nyaman, produkstif, dan berkelanjutan [4].

Perkembangan konversi lahan di perkotaan bergeraknya sangat cepat, sehingga terjadi overlap antara realita di lapangan dengan rencana pemerintah yang membutuhkan waktu lama. Sebagai antisipasi, kenyataan ini mengharuskan tersedianya data yang lengkap, akurat dan cepat guna mengimbangi mengejalanya kegiatan konversi lahan. Salah satu solusi yang dapat digunakan melalui simulasi pemodelan menggunakan aplikasi dari sistem informasi geografis (SIG). Simulasi pemodelan dimaksudkan untuk memprediksi zona kemungkinan yang akan mengalami konversi lahan akibat beberapa faktor yang diduga mempengaruhinya, seperti jaringan jalan, kemiringan lereng, penggunaan lahan, pasar, 
lokasi pemerintahan atau pun pusat pendidikan, sehingga dapat menyediakan data yang cepat mengenai estimasi perkembangan fisik kota ditengah pesatnya kegiatan konversi lahan. Keseluruhan data akan diproses dan dianalisis melalui software SIG.

\section{SIG UNTUK PEMODELAN SPASIAL PERKEMBANGAN FISIK KOTA (URBAN SPRAWL)}

Menurut Aronoff [5] SIG merupakan sistem berbasis komputer yang digunakan untuk menyimpan dan memanipulasi informasi-informasi geografis. Pendapat yang serupa juga diungkapkan oleh Maguire [6] yang lebih menekankan SIG dari perspektif teknologi dengan difokuskan pada aspek fungsionalnya yang meliputi peta, basis data, dan analisis spasial. Berdasarkan kedua pendapat para ahli tersebut tersirat makna bahwa SIG berhubungan erat dengan komputer dan data yang bereferensi geografis/geospasial. Sebagai suatu sistem, tentunya akan mempunyai sub sistem yang menjadi bagiannya. Begitu juga pada SIG, terdiri dari berbagai sub sistem. Menurut referensi [6], dengan pertimbangan berbagai macam definisi dari beberapa ahli mengenai SIG, maka sub sistem SIG di terdiri dari:

a. Data input, merupakan tahapan mengumpulkan, mempersiapkan, dan menyimpan data spasial atau atributnya dari berbagai sumber.

b. Data output, merupakan tahapan untuk menampilkan atau menghasilkan seluruh atau sebagian basisdata dalam bentuk softcopy maupun hardcopy yang berupa tabel, grafik, maupun peta.

c. Data management, merupakan bagaimana sub sistem ini mengorganisasikan baik data spasial maupun tabel-tabel atribut ke dalam sebuah basis data sehingga mudah dipanggil kembali (retrievel).

d. Data manipulation \& analisis, merupakan tahapan yang menentukan informasiinformasi yang akan dihasilkan oleh SIG.

SIG dapat merepresentasikan suatu model dunia nyata di atas layar monitor komputer sebagaimana lembaran-lebaran peta dapat merepresentasikan dunia nyata di atas kertas. Diantara berbagai sub sistem SIG, salah satu yang mencirikan SIG dengan software yang lain adalah kemampuannya dalam melakukan fungsi analisis spasial dan atribut. Proses menjawab pertanyaanpertanyaan tersebut melalui sistem kerja SIG adalah mengolah dan mengelola data spasial dan non-spasial dengan volume yang cukup besar yang kemudian diintegrasikan secara matematis dengan menerapkan beberapa operasi aritmatika dan logika sehingga memunculkan suatu solusi atau jawaban [6]. Sebagai ilustrasinya disajikan pada Gambar 1.

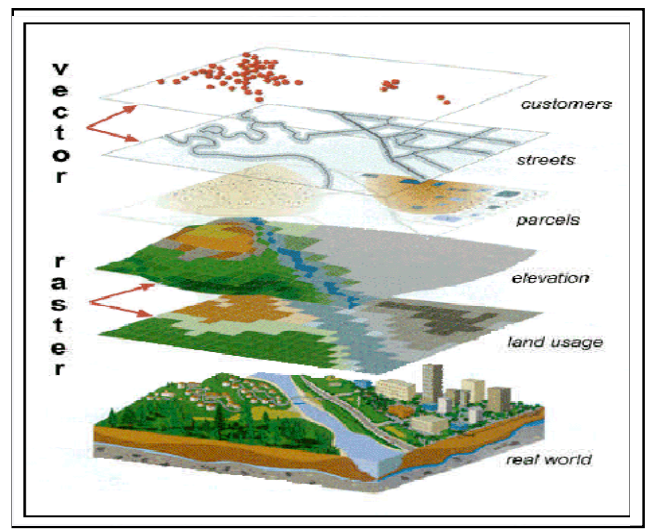

Gambar 1. Contoh overlay data spasial pada SIG

[7]

Merujuk pada Gambar 1, salah satu yang akan menjadi implementasi SIG dalam makalah ini adalah menentukan zona terjadinya perkembangan fisik kota. Dasar pemikirannya adalah dengan menggunakan aplikasi SIG yang dipadukan dengan beberapa data spasial berupa indikator pengaruh perkembangan kota yang diberi bobot, maka akan dilakukan proses analisis untuk menentukan zona perkembangan fisik kota.

\section{PELAKSANAAN KEGIATAN}

Kegiatan ini dilakukan secara bertahap yang meliputi beberapa tahapan. Secara umum dasar pemikiran yang digunakan dalam kegiatan ini dituangkan melalui diagram alir pada Gambar 2.

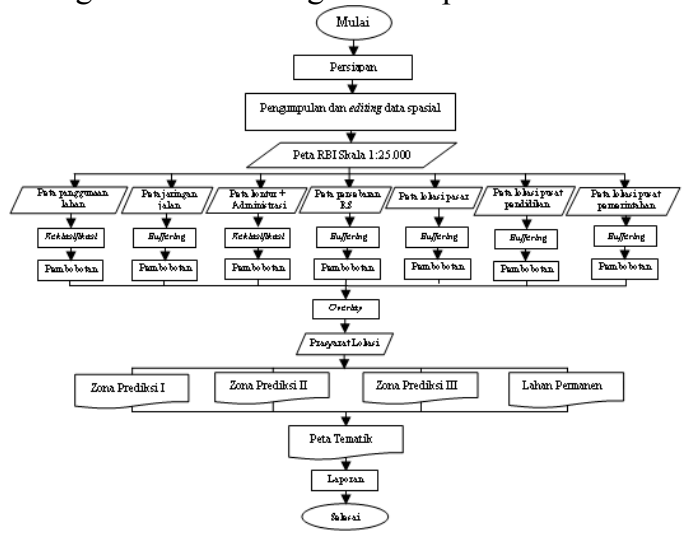

Gambar 2. Diagram alir penelitian

Berdasarkan diagram alir pada Gambar 2, maka secara sistematis tahapan yang dilakukan untuk 
menentukan prediksi perkembangan fisik Kota Singaraja, sebagai berikut.

III.1 Tahap Persiapan

Pada tahap persiapan dikategorikan menjadi dua yaitu tahap persiapan teknis dan persiapan bahan (non-teknis).

a. Persiapan teknis adalah melakukan persiapan terhadap perangkat-perangkat keras (hadware) dan perangkat lunak (software) yang digunakan selama pemrosesan data.

b. Persiapan bahan (non-teknis)adalah melakukan persiapan terhadap bahan-bahan yang akan digunakan/diproses dalam tahap analisis data, yang meliputi:

- Peta Penggunaan Lahan Kota Singaraja

- Peta Jaringan Jalan Kota Singaraja

- Peta Batas Administrasi Kota Singaraja

- Peta Kontur Kota Singaraja

- Peta Lokasi Pasar Kota Singaraja

- Peta Lokasi Sekolah Kota Singaraja

- Peta Lokasi Pusat Pemerintahan Kota Singaraja

- Peta Persebaran Rumah Sakit Kota Singaraja

Keseluruhan data tersebut diturunkan dari peta RBI skala 1:25.000 yang diakuisisi pada tahun 1999

\section{III.2 Tahap Pengumpulan Data}

Proses pengumpulan data spasialmeliputi: (1) peta penggunaan lahan, (2) peta jaringan jalan, (3) peta batas administrasi, (4) peta kontur, (5) peta lokasi pasar, (6) peta lokasi sekolah, (7) peta lokasi pusat pemerintahan, dan (8) peta lokasi rumah sakit. Keseluruhan data tersebut diperoleh dari Jurusan Pendidikan Geografi Undiksha Singaraja yaitu pada arsip peta RBI wilayah Pulau Bali.

III.3 Tahap Pengolahan dan Analisis Data

Pengolahan dan analisis data secara langsung dilakukan di Lab Geodesi Fakultas Teknik UGM. Secara sistematis berikut akan disajikan mengenaitahapan proses pengolahan dan analisis data.

a. Tahap pemberian bobot terhadap kriteria faktor pendorong perkembangan kota.

Kriteria yang digunakan sebagai faktor untuk memprediksi perkembangan fisik kota meliputi: (1) jenis penggunaan lahan, (2) kedekatan dengan fasilitas kota, seperti jalan utama, pasar, fasilits pendidikan, dan fasilitas pemerintahan, dan (3) kondisi topografi wilayah [8]. Berdasarkan keseluruhan kriteria yang digunakan untuk menentukan pemodelan perkembangan fisik kota, maka pada makalah

ini hanya difokuskan pada beberapa faktor sesuai dengan ketersediaan data. Beberapa faktor yang dimaksud tersebut kemudian diberikan bobot sesuai dengan kontribusi faktor pengaruhnya, sebagai berikut.

Tabel I

Bobot Penggunaan Lahan

\begin{tabular}{|c|c|}
\hline Kriteria & Bobot \\
\hline Permukiman & 1 \\
\hline Tegalan & 2 \\
\hline Perkebunan & 3 \\
\hline Sawah irigasi & 4 \\
\hline
\end{tabular}

Tabel III Bobot Kemiringan Lereng

\begin{tabular}{|c|c|}
\hline Kriteria & Bobot \\
\hline $0-8 \%$ & 5 \\
\hline $9-17 \%$ & 4 \\
\hline $18-26 \%$ & 3 \\
\hline $27-35 \%$ & 2 \\
\hline$>35 \%$ & 1 \\
\hline
\end{tabular}

Tabel V

Bobot Jarak dari

Lokasi Sekolah

\begin{tabular}{|c|c|}
\hline Kriteria & Bobot \\
\hline $0-250 \mathrm{~m}$ & 5 \\
\hline $250-500 \mathrm{~m}$ & 4 \\
\hline \begin{tabular}{c}
$500-750 \mathrm{~m}$ \\
\hline $\begin{array}{c}750-1000 \\
\mathrm{~m}\end{array}$
\end{tabular} & 2 \\
\hline$>1000 \mathrm{~m}$ & 1 \\
\hline
\end{tabular}

Tabel II

Bobot Jarak dari Lokasi Pasar

\begin{tabular}{|c|c|}
\hline Kriteria & Bobot \\
\hline $0-200 \mathrm{~m}$ & 4 \\
\hline $200-400 \mathrm{~m}$ & 3 \\
\hline $400-600 \mathrm{~m}$ & 2 \\
\hline$>600 \mathrm{~m}$ & 1 \\
\hline
\end{tabular}

Tabel IV Bobot Jaringan Jalan

\begin{tabular}{|c|c|}
\hline Kriteria & Bobot \\
\hline $0-500 \mathrm{~m}$ & 5 \\
\hline $500-1000 \mathrm{~m}$ & 4 \\
\hline $\begin{array}{c}1000-1500 \\
\mathrm{~m}\end{array}$ & 3 \\
\hline $\begin{array}{c}1500-2000 \\
\mathrm{~m}\end{array}$ & 2 \\
\hline$>200 \mathrm{~m}$ & 1 \\
\hline
\end{tabular}

Tabel VI

Bobot Jarak dari Pusat

Pemerintahan

\begin{tabular}{|c|c|}
\hline Kriteria & Bobot \\
\hline $0-1000 \mathrm{~m}$ & 5 \\
\hline $\begin{array}{c}1000-2000 \\
\mathrm{~m}\end{array}$ & 4 \\
\hline $\begin{array}{c}2000-3000 \\
\mathrm{~m}\end{array}$ & 3 \\
\hline $\begin{array}{c}3000-4000 \\
\mathrm{~m}\end{array}$ & 2 \\
\hline$>4000 \mathrm{~m}$ & 1 \\
\hline
\end{tabular}

Tabel VII

Bobot Jarak dari Lokasi Rumah Sakit

\begin{tabular}{|c|c|}
\hline Kriteria & Bobot \\
\hline $0-500 \mathrm{~m}$ & 4 \\
\hline $500-1000 \mathrm{~m}$ & 3 \\
\hline $1000-1500 \mathrm{~m}$ & 2 \\
\hline$>1500 \mathrm{~m}$ & 1 \\
\hline
\end{tabular}

Bobot yang digunakan seperti pada Tabel I-VII didasarkan pada prioritas kontribusi setiap faktor yang mempengaruhi perkembangan fisik kota [8]. Semakin tinggi bobot yang digunakan, maka akan semakin besar pengaruhnya terhadap prediksi perkembangan fisik kota.

b. Proses analisis spasial dengan menggunakan software SIG (ArcGIS 10).

Proses analisis spasial yang dilakukan untuk masing-masing data yaitu:

1. Kriteria penggunaan lahan dilakukan proses reklasifikasi dengan menggunakan fasilitas 


\section{:3DAnalyst Tools $\rightarrow$ Raster Reclass $\rightarrow$ Reclassify.}

2. Kriteria jarak dari lokasi pasar dilakukan proses Buffermelalui fasilitasAnalysis Tools $\rightarrow$ Proximity $\rightarrow$ Multiple Ring Buffer.

3. Kriteria kemiringan lereng dilakukan proses pembuatan TIN (Triangular Irregular Network), kemudian dikonversi dan direklasifikasi menggunakan fasilitas 3DAnalyst Tools $\rightarrow$ Raster Reclass $\rightarrow$ Reclassify.

4. Kriteria jaringan jalan dilakukan proses Buffermelalui fasilitasAnalysis Tools $\rightarrow$ Proximity $\rightarrow$ Multiple Ring Buffer.

5. Kriteria jarak dari lokasi sekolah dilakukan proses Buffermelalui fasilitasAnalysis Tools $\rightarrow$ Proximity $\rightarrow$ Multiple Ring Buffer.

6. Kriteria jarak dari pusat pemerintahan dilakukan proses Buffermelalui fasilitasAnalysis Tools $\rightarrow$ Proximity $\rightarrow$ Multiple Ring Buffer.

7. Kriteria jarak dari lokasi rumah sakit dilakukan proses Buffermelalui fasilitasAnalysis Tools $\rightarrow$ Proximity $\rightarrow$ Multiple Ring Buffer.

c. Overlay data spasial.

Setelah keseluruhan data spasial dilakukan analisis dan diberikan bobot, kemudian dilakukan proses overlay dengan menggunakan fasilitas Analysis Tools $\rightarrow$ Overlay $\rightarrow$ Union.

d. Penentuan prediksi zona perkembangan fisik kota.

Proses penentuan prediksi zona perkembangan fisik kota mengacu pada klasifikasi pembototan yang sudah ditentukan, yaitu :

- $\quad$ Bobot $\geq 25$ dan bukan permukiman, maka dikategorikan prediksi zona I.

- Bobot 16-24 dan bukan permukiman, maka dikategorikan prediksi zona II.

- Bobot 7-15 dan bukan permukiman, maka dikategorikan prediksi zona III.

- Apabila penggunaan lahan permukiman, maka dikategorikan sebagai lahan permanen.

\section{HASIL DAN PEMBAHASAN}

Berdasarkan dari proses analisis SIG yang diintergrasikan dengan berbagai faktor pengaruh perkembangan fisik kota, maka visualisasi prediksi perkembangan fisikKota Singaraja disajikan pada Gambar 3.

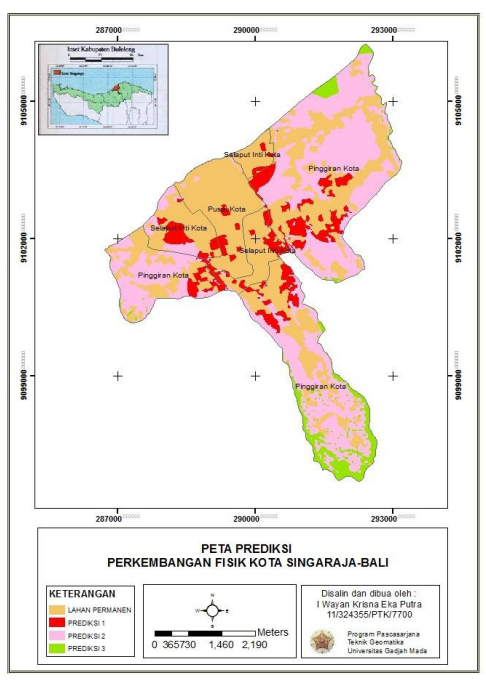

Gambar 3. Prediksi Perkembangan Fisik Kota Singaraja

Gambar 3 merupakan hasil prediksi perkembangan fisik Kota Singaraja yang diperoleh melalui analisis Sistem Informasi Geografis dengan menggunakan teknik overlay beberapa data spasial yang mempengaruhi perkembangan fisik kota. Berdasarkan visualisasi dari prediksi perkembangan fisik KotaSingaraja tersebut, dapat dijelaskan sebagai berikut.

a. Pada inti kota diprediksi akan terjadi perubahan penggunaan lahan untuk permukiman dan atau kawasan perindustrian mencapai 3.213.363,14 $\mathrm{m}^{2}$ yang rinciannya $211.961,181 \mathrm{~m}^{2}$ kategori prediksi I, 2.494.542,33 $\mathrm{m}^{2}$ kategori prediksi II dan $8,084 \mathrm{~m}^{2}$ kategori prediksi III.

b. Pada selaput inti kota diprediksi akan terjadi perubahan penggunaan lahan untuk permukiman dan atau kawasan perindustrian mencapai $5.766 .316,95 \mathrm{~m}^{2}$ yang rinciannya $1.194 .744 \mathrm{~m}^{2}$ kategori prediksi I, 4.571.400 $\mathrm{m}^{2}$ kategori prediksi II dan 173,57 $\mathrm{m}^{2}$ kategori prediksi III.

c. Pada daerah pinggiran kota diprediksi akan terjadi perubahan penggunaan lahan untuk permukiman dan atau kawasan perindustrian mencapai $12.451 .201 \mathrm{~m}^{2}$ yang rinciannya $1.782 .097 \mathrm{~m}^{2}$ kategori prediksi I, 9.403.553 $\mathrm{m}^{2}$ kategori prediksi II, dan $1.265 .551 \mathrm{~m}^{2}$ kategori prediksi III.

Berdasarkan analisis spasial, pada bagian inti kota akan sangat berpotensi digunakanuntuk lokasi permukiman dan atau lokasi perindustrian serta sarana umum lainnya. Hal ini diduga dipengaruhi oleh keberadaan lokasi yang masih 
berada di pusatkota beserta keberadaan fasilitas umum seperti lokasi pasar, rumah sakit, pusatpemerintahan maupun sekolah. Masyarakat cenderung akan memilih lokasi dekat denganpusat kota dan fasilitas umum dengan pertimbangan aksesibilitas, walaupun tidak jarang ada yang sengaja memilih lokasi di pinggiran kota. Tidak hanya di bagian inti kota,prediksi yang dikategorikan paling potensial (kategori I) juga merambah sebagai daerah selaput intidan daerah pinggiran kota. Berdasarkan pengamatan di lapangan, keberadaan lokasitersebut dipengaruhi oleh beberapa lokasi sarana umum yang menjadi faktor penariklimpahan masyarakat untuk bermukim di sekitarnya, seperti terdapatnya sekolah, rumah sakit, maupun pasar.

Mempertimbangkan kemungkinan peningkatan jumlah penduduk dan juga keterbatasan ruang, maka tidakhanya terbatas pada bagian inti kota, perkembangan fisik kota juga akan terjadi di bagian selaput inti dan di pinggiran kota. Sesuai hasil analisis spasial, bahwa diprediksi juga lokasi kategori II yang berpotensi mengalamiperkembangan terjadi pada daerah selaput inti kota. Hal ini diduga dipengaruhi olehjumlah penduduk akan selalu mengalami peningkatan, sehingga penduduk akan bergerakke arah pinggir kota untuk mengembangkan permukiman ataupun kawasan industri. Secarakhusus pada bagian daerah pinggiran kota juga diprediksi akan berpotensi mengalami perkembangan. Hal iniakan terjadi apabila untuk zona I dan zona II sudah tidak menyisakan lahan lagi, sehinggasebagian masyarakat yang ingin menetap di Kota Singaraja akan memilih lokasi yangmasih memungkinkan untuk permukiman atau kegiatan industri yaitu zona III ini, tetapitidak jarang juga sebagian masyarakat sengaja untuk mengembangkan permukiman danatau lokasi perindustrian di daerah pinggiran kota dengan alasan kenyamanan.

Sebagai ilustrasi untuk mevalidasi hasil prediksi, maka peta hasil prediksi dapat dikonversi menjadi format. $\mathrm{kml}$, dan selanjutnya bisa dioverlay dengan citra Google Earth yang menyajikan kondisi eksisting saat ini. Hasilnya disajikan melalui Gambar 4.

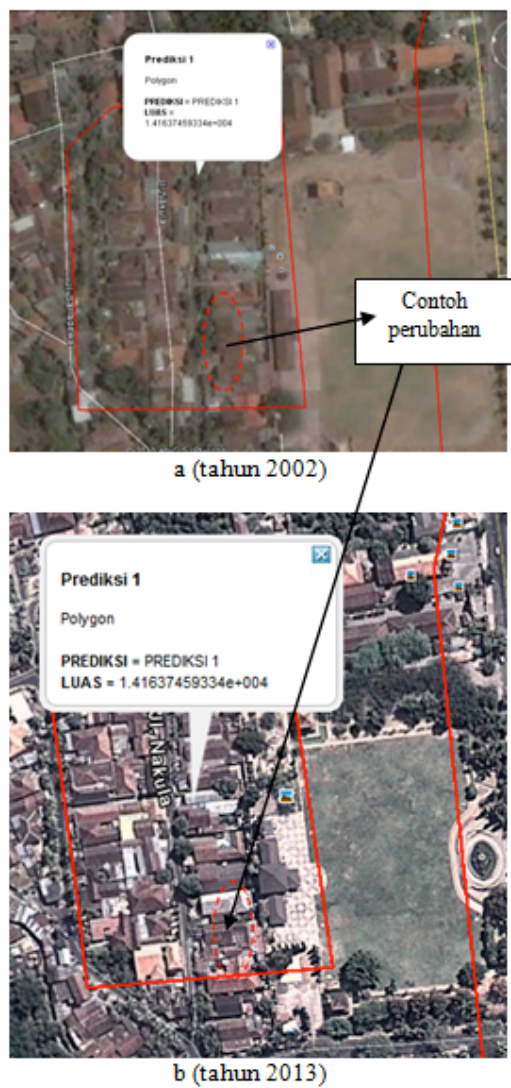

Gambar 4. Overlay hasil prediksi pada citra Google Earth

Berdasarkan Gambar 4, tersajikan ilustrasi validasi hasil prediksi dengan kondisi eksisting pada citra Google Earth tahun 2013. Pada gambar tersebutmemperlihatkan selama tahun 2002-2013 telah terlihat adanya perubahan penggunaan lahan pada lokasi yang diprediksi akan mengalami perkembangan fisik kota. Kondisi tersebut dapat memperjelas mengenai keefektivitasan dari hasil prediksi yang diperoleh.

\section{SIMPULAN}

Berdasarkan hasil analisis data spasial mengenai prediksi perkembangan fisik Kota Singaraja, dapat disimpulkan bahwa lokasi yang paling potensial akan mengalami perkembangan fisik kota terjadi di bagian inti kota dan sebagian merambah bagian selaput inti kota serta pinggiran kota. Arah perkembangan kota diprediksi menyebar secara merata ke segala arah atau mengikuti pola perkembangan secara konsentris, kecuali ke arah utara karena bagian utara Kota Singaraja merupakan wilayah laut. 
ISSN 2089-8673

Jurnal Nasional Pendidikan Teknik Informatika (JANAPATI)

Volume 2, Nomor 3, Desember 2013

\section{REFERENSI}

[1] Antara, Made, 2002. Dampak Konversi Lahan Pertnian Terhadap Produksi Pangan Nasional : Suatu refleksi Menyambut Hari Pangan Sedunia 16 Oktober 2002. Tersedia pada http://www.scribd.com/doc/63414775/Artikel-Bali Post, diakses pada Selasa 29 Mei 2012.

[2] Departemen Dalam Negeri RI. 2004. Pemerintahan Daerah. UU No. 32 Tahun 2004.

[3] Tallo, Octas B; Subaryono; Harintaka. 2006. Pemanfaatan Citra Landsat 7 ETM+ Untuk Evaluasi Penggunaan Lahan Dalam Rencana Umum Tata Ruang Wilayah Kabupaten Timor Tengan Selatan.
Disampaikan dalam Pertemuan Ilmiah Tahunan III Teknik Geomatika ITS.

[4] Departemen Dalam Negeri RI. 2007. Rencana Tata Ruang Wilayah (RTRW). UU No 26 Tahun 2007.

[5] Elly, Muhamad Jafar. 2009. Sistem Informasi Geografi. Graha Ilmu: Yogyakarta

[6] Prahasta, Eddy. 2009. Sistem Informasi Geografis. Informatika : Bandung.

[7] ESRI. 1996. Working With the Arc View spatial analyst.

[8] Ahmadi. 2005. Faktor-Faktor Yang Mempengaruhi Perkembangan Fisik Area Pinggir Kota Berdasarkan Aspek Persepsi Bermukim Pada Kota Sengkang Propinsi Sulawesi Selatan. Tesis (tidak diterbitkan). Universitas Diponogoro : Semarang 